\title{
Short communication: Evaluation of the accuracy of an electronic on-farm test to quantify blood $\beta$-hydroxybutyrate concentration in dairy goats
}

\author{
V. Doré, J. Dubuc, ${ }^{1}$ A. M. Bélanger, and S. Buczinski \\ Département de sciences cliniques, Faculté de médecine vétérinaire, CP 5000, Université de Montréal, Saint-Hyacinthe, Québec, J2S 7C6, \\ Canada
}

\begin{abstract}
The objective of this cross-sectional study was to validate the accuracy of a hand-held electronic onfarm test (Precision Xtra) for quantifying the blood $\beta$-hydroxybutyrate (BHBA) concentration in dairy goats. A total of 114 dairy goats from 3 commercial herds were sampled once for blood in the jugular vein between 1 mo before and 2 mo after parturition. Blood samples were centrifuged to harvest serum and sera were sent to the Animal Health Laboratory of the Université de Montréal for quantification of BHBA concentration (gold standard). Laboratory BHBA values were between 0.1 and $3.7 \mathrm{mmol} / \mathrm{L}$. Precision Xtra values were compared with gold standard values; Pearson correlation coefficient was 0.98 and coefficient of determination was 0.95 . Overall, these results suggested that Precision Xtra provides excellent accuracy for measuring blood BHBA concentration in dairy goats compared with the gold standard test.
\end{abstract}

Key words: dairy goat, $\beta$-hydroxybutyrate, Precision Xtra, ketosis

\section{Short Communication}

$\beta$-Hydroxybutyrate and other ketone bodies are found in the blood, milk, and urine of ruminants experiencing a period of negative energy balance (Herdt, 2000). In dairy goats, blood BHBA concentration generally increases during late stage of pregnancy (Herdt, 2000; Radostis et al., 2007; Brozos et al., 2011) and may be associated with clinical signs of pregnancy toxemia (Hefnawy et al., 2010) and ketosis (Smith and Sherman, 2009). Early detection of pregnancy toxemia and ketosis by measurement of BHBA concentration might be useful because these diseases generally have a poor prognosis for production and survival (Brozos et al., 2011). The gold standard diagnostic test for pregnancy toxemia and ketosis in goats is the measurement of

Received October 29, 2012.

Accepted March 11, 2013.

${ }^{1}$ Corresponding author: jocelyn.dubuc@umontreal.ca
BHBA in serum or plasma (Rook, 2000). Such a procedure relies on specific laboratory equipment and implies that serum samples be shipped to a laboratory, which is inconvenient. An electronic on-farm test for the quantification of blood BHBA concentration (Precision Xtra, Abbott Diabetes Care, Saint-Laurent, Canada), was recently validated in dairy cows and showed excellent accuracy $(\mathrm{r}=0.95-0.97$; Iwersen et al., 2009; Voyvoda and Erdogan, 2010); similar results have also obtained for sheep and cats (Panousis et al., 2012; Weingart et al., 2012). However, the accuracy of this device in goats remains unknown. Therefore, the objective of this study was to validate the accuracy of an electronic onfarm test (Precision Xtra) for quantifying blood BHBA concentration in dairy goats.

A cross-sectional study was conducted in November 2011 with a total of 114 dairy goats from 3 commercial dairy farms enrolled. Sample size calculation was based on showing a statistically significant difference between quantitative data results from 2 methods measuring BHBA concentration in serum (laboratory; mean value $=0.70 \mathrm{mmol} / \mathrm{L}$ ) and blood (Precision Xtra; mean value $=0.80 \mathrm{mmol} / \mathrm{L}$ ) considering a standard deviation value of $0.2 \mathrm{mmol} / \mathrm{L}$, and errors I and II values of 0.05 and 0.10, respectively. Farm selection was based on convenience (vicinity of the ruminant field service clinic of the Université de Montréal, Saint-Hyacinthe, Canada). This project was approved by the Animal Care Committee of the Université de Montréal before commencement of the study. Each farm was visited once and goats between 1 mo before and 2 mo after parturition were enrolled. Each animal was only used once during the study period. Participating goats were manually restrained and a blood sample $(10 \mathrm{~mL})$ was collected from the jugular vein with a 20-gauge needle using a vaccum tube without anticoagulant (BD Vacutainer, BD, Franklin Lakes, NJ). A hand-held electronic device (Precision Xtra) was immediately used to quantify blood BHBA concentration after dipping the device sensor onto the blood surface in the collection tube (Iwersen et al., 2009). The same device was used for all participating goats. Animal identification and blood BHBA concentration data were collected on 
farms. Blood samples were kept on ice in a cooler after sampling and were brought to the ruminant field service clinic of the Université de Montréal within $3 \mathrm{~h}$ after collection. Blood tubes were then centrifuged $(1,000 \times g$ for $10 \mathrm{~min}$ at $4^{\circ} \mathrm{C}$ ) and serum was harvested. Sera were stored in freezer $\left(-18^{\circ} \mathrm{C}\right)$ until all samples were collected. Serum BHBA concentrations were determined at the Animal Health Laboratory of the Université de Montréal using colorimetric enzymatic reaction (Ranbut D-3-hydroxybutyrate kit, Randox Laboratories Canada, Mississauga, Canada) with an automated serum analyzer (Hitachi 911, Roche Diagnostics, Indianapolis, IN). The analytical sensitivity of BHBA assay was $0.1 \mathrm{mmol} / \mathrm{L}$. The inter- and intra-assay coefficients of variation were 5.25 and $3.73 \%$, respectively. Data were compiled using Microsoft Excel (version 2012; Microsoft Corp., Redmond, WA). Statistical analyses were performed with SAS (version 9.3; SAS Institute Inc., Cary, NC); the statistician was blinded to BHBA measurement tools. Descriptive statistics were calculated. Serum and blood BHBA values were analyzed as continuous variables and compared using the CORR procedure to calculate Pearson correlation coefficient and coefficient of determination. Figures were made with SigmaPlot (version 12; Systat Software Inc., San Jose, CA).

Data from 114 dairy goats were compiled and used in this study. Frequency distribution of blood (Precision Xtra) and serum (laboratory) BHBA results are presented in Figure 1. Minimum and maximum blood BHBA values were 0.1 and $3.7 \mathrm{mmol} / \mathrm{L}$, respectively. Mean $( \pm \mathrm{SD})$ and median (first and third quartiles) blood BHBA values were $0.5( \pm 0.6) \mathrm{mmol} / \mathrm{L}$ and 0.3 $(0.2,0.6) \mathrm{mmol} / \mathrm{L}$, respectively. Mean $( \pm \mathrm{SD})$ and median (first and third quartiles) serum BHBA values were $0.5( \pm 0.4) \mathrm{mmol} / \mathrm{L}$ and $0.4(0.3,0.5) \mathrm{mmol} / \mathrm{L}$, respectively. The Pearson correlation coefficient between blood and serum BHBA results was $0.98(P<0.01$; Figure 2; $\left.\mathrm{R}^{2}: 0.95\right)$.

Our data showed a Pearson correlation coefficient (r $=0.98)$ similar to other studies investigating the same in dairy sheep $(\mathrm{r}=0.99$; Panousis et al., 2012) and cows $(\mathrm{r}=$ 0.95-0.97; Iwersen et al., 2009; Voyvoda and Erdogan, 2010). Therefore, Precision Xtra has an excellent accuracy compared with the gold standard test. Nonetheless, it must be kept in mind that the current study provided low BHBA values, $>2.0 \mathrm{mmol} / \mathrm{L}$. It remains unclear at this time if goats frequently experience blood BHBA values greater than $2.0 \mathrm{mmol} / \mathrm{L}$. High values are common in dairy cows and sheep and may be as high as 7.5 and $5.4 \mathrm{mmol} / \mathrm{L}$, respectively (Iwersen et al., 2009; Panousis et al., 2012). In such cases, the accuracy of Precision Xtra may need to be further validated, although results in the current study suggest good ac- curacy. Based on other studies performed in cows and sheep (Iwersen et al., 2009; Voyvoda and Erdogan, 2010; Panousis et al., 2012), it may be assumed that the accuracy of Precision Xtra in regard to high-blood BHBA values is excellent and similar to lower values. The objective of the current study was not to determine BHBA thresholds associated with greater risk of clinical diseases, such as pregnancy toxemia and ketosis. The BHBA threshold in sheep for predicting subclinical pregnancy toxemia was suggested to be $0.8 \mathrm{mmol} / \mathrm{L}$ (Rook, 2000) and between 1.2 and $1.4 \mathrm{mmol} / \mathrm{L}$ in cows for predicting displaced abomasum and clinical ketosis (Duffield et al., 2009). Further research is needed in
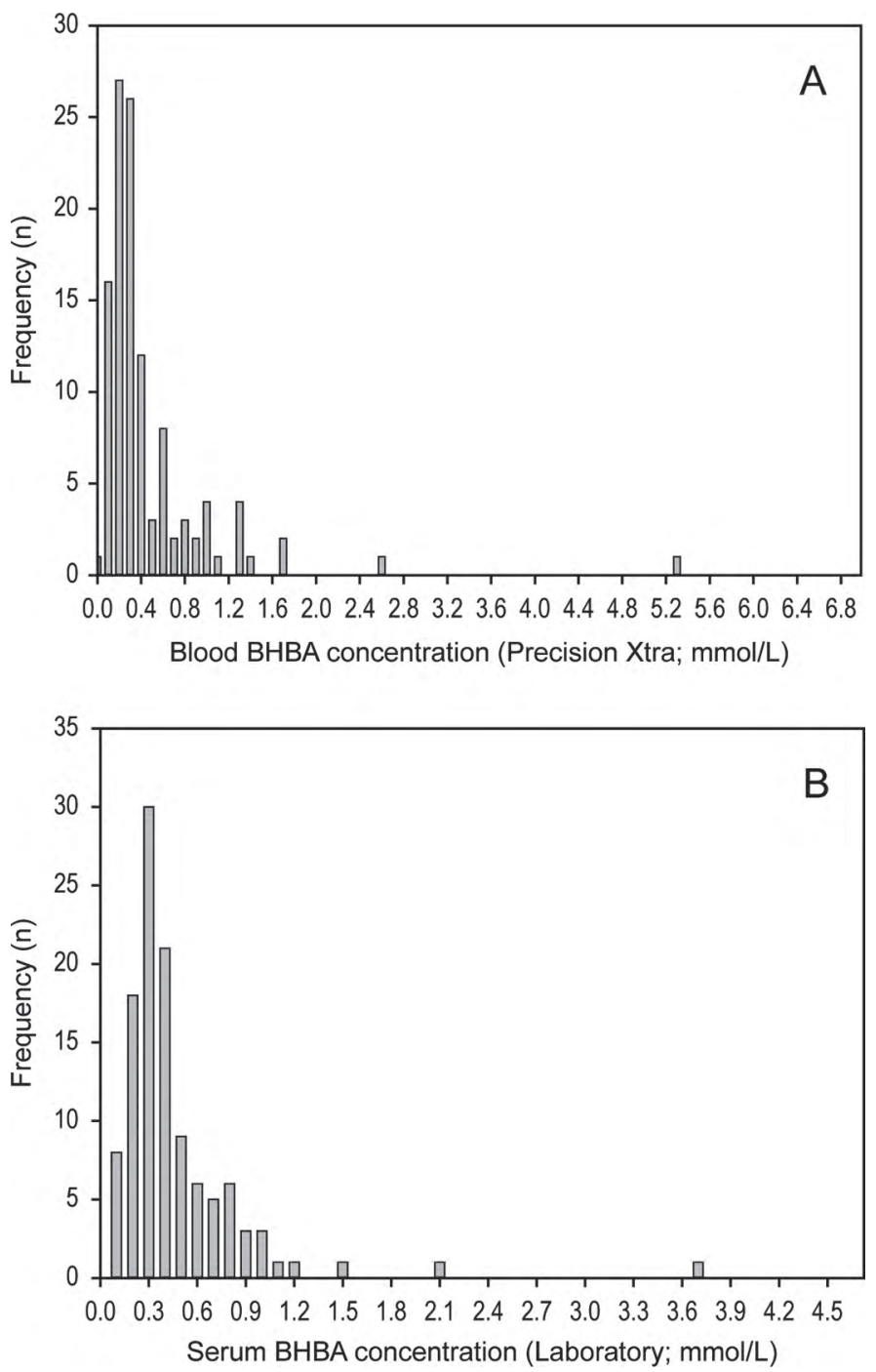

Figure 1. Frequency distribution of BHBA concentration values measured in whole blood with Precision Xtra (Abbott Diabetes Care, Saint-Laurent, Canada; A) and in serum with gold standard laboratory test (B) from 114 dairy goats sampled in jugular vein from 1 mo before to 2 mo after parturition. 


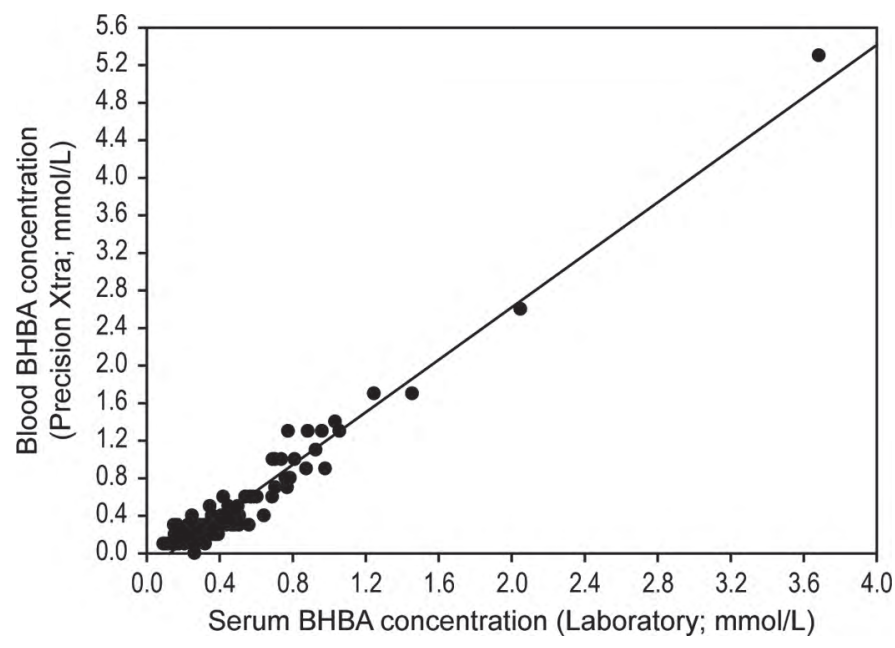

Figure 2. Regression plot $\left(\mathrm{r}=0.98 ; \mathrm{R}^{2}=0.95 ; P<0.01\right)$ of blood BHBA concentration (Precision Xtra; Abbott Diabetes Care, SaintLaurent, Canada) compared with serum BHBA concentration (laboratory) in 114 dairy goats sampled in jugular veins from 1 mo before to 2 mo after parturition.

dairy goats to determine such thresholds associated pregnancy toxemia and ketosis.

In conclusion, the accuracy of Precision Xtra for measuring blood BHBA concentration in dairy goats is excellent when compared with the gold standard test. Therefore, producers, veterinary practitioners, and animal scientists may reliably use the Precision Xtra device for monitoring ketonemia in dairy goats.

\section{ACKNOWLEDGMENTS}

We acknowledge La Société des Éleveurs de Chèvres Laitières de Race du Québec (Saint-Hyacinthe, Québec, Canada) and the Canadian Agricultural Adaptation
Program (CAAP) from Agriculture and Agri-Food Canada (Ottawa, Ontario, Canada) for funding this project. We also thank the participating farmers and technical staff for their help during the project.

\section{REFERENCES}

Brozos, C., V. S. Mavrogianni, and G. C. Fthenakis. 2011. Treatment and control of peri-parturient metabolic diseases: Pregnancy toxemia, hypocalcemia, hypomagnesemia. Vet. Clin. North Am. Food Anim. Pract. 27:105-113. http://dx.doi.org/10.1016/j. cvfa.2010.10.004.

Duffield, T. F., K. D. Lissemore, B. W. McBride, and K. E. Leslie. 2009. Impact of hyperketonemia in early lactation dairy cows on health and production. J. Dairy Sci. 92:571-580.

Hefnawy, A. E., S. Youssef, and S. Shousha. 2010. Some immunohormonal changes in experimentally pregnant toxemic goats. Vet. Med. Int. 10:1-5. http://dx.doi.org/10.4061/2010/768438.

Herdt, T. H. 2000. Ruminant adaptation to negative energy balance: Influences on the etiology of ketosis and fatty liver. Vet. Clin. North Am. Food Anim. Pract. 16:215-230.

Iwersen, M., U. Falkenberg, R. Voigtsberger, D. Forderung, and W. Heuwieser. 2009. Evaluation of an electronic cowside test to detect subclinical ketosis in dairy cows. J. Dairy Sci. 92:2618-2624. http://dx.doi.org/10.3168/jds.2008-1795.

Panousis, N., C. Brozos, I. Karagiannis, N. D. Giadinis, S. Lafi, and M. Kritsepi-Konstantinou. 2012. Evaluation of Precision Xceed meter for on-site monitoring of blood $\beta$-hydroxybutyric acid and glucose concentrations in dairy sheep. Res. Vet. Sci. 93:435-439. http://dx.doi.org/10.1016/j.rvsc.2011.06.019.

Radostits, O. M., C. C. Gay, K. W. Hinchcliff, and P. D. Constable. 2007. Pregnancy toxemia in sheep. Pages 1668-1671 in Veterinary Medicine. 10th ed. Saunders Elsevier, Philadelphia, PA.

Rook, J. S. 2000. Pregnancy toxemia of ewes, does, and beef cows. Vet. Clin. North Am. Food Anim. Pract. 16:293-317.

Smith, M., and D. Sherman. 2009. Nutrition and metabolic diseases. Pages 733-783 in Goat Medicine. 2nd ed. Wiley-Blackwell, Ames, IA.

Voyvoda, H., and H. Erdogan. 2010. Use of a hand-held meter for detecting subclinical ketosis in dairy cows. Res. Vet. Sci. 89:344351. http://dx.doi.org/10.1016/j.rvsc.2010.04.007.

Weingart, C., F. Lozt, and B. Kohn. 2012. Validation of a portable hand-held whole-blood ketone meter for use in cats. Vet. Clin. Pathol. 41:114-118. http://dx.doi.org/10.1111/j.1939165X.2011.00389.x. 